\title{
Beyond Watt Market Roundabout Audiences: Redesigning Tourists Oriented Theatres in Calabar
}

\author{
Edisua Merab Yta \\ Department of Theatre, Film and Carnival Studies, \\ University of Calabar, Calabar, Cross River State Nigeria. \\ Email: edisuamerab@unical.edu.ng
}

\begin{abstract}
Calabar, a coastal town in South-South Nigeria, has had a long-standing history of cultural touristoriented theatre performances. And today, its image as a tourist city has grown in leaps because of the Christmas Festival (A 32-day entertainment art and cultural events) it hosts annually plus other tourism products or attractions that complement the festival. Carnival seems to be a major attraction. Other attractions are not emphasized. This study explored how tourism-oriented theatres can be developed to add to existing attractions and increase varieties for tourists. The study used a combination of research methods including experiential theatre performances, participant observation, and focus group discussion. Findings show that local culture and arts and creative industries i.e., theatre can be used to promote destinations and enhance their attractiveness. They can help build the image of the city and promote indigenous arts and culture. This research significantly models the utility of theatre in the service of tourism and urban development. Some key recommendations this research makes include, the collaboration of the tourism industry, the performing arts sectors, and private business owners. Creating demand and market for specially packaged theatre products for tourists working with travel agencies to ensure that theatre is taken from the mainstream to the tourists.
\end{abstract}

Keywords: Theatre; Tourism; Calabar; Redesigning

\section{INTRODUCTION}

One of the primary roles of theatre is entertainment. From the dawn of its history theatre has thrilled its audiences across cultures, civilizations and periods. Jordan Miller in the Heath Introduction to Drama writes:

Ever since the first pre-historic hunters returned from the hunt to elaborate on the size of a saber-toothed tiger that got away every major culture has at one time or the other possessed a highly developed tradition of theatre...we who watch expect to experience some form of emotional pleasures. One can expect to be excited, mystified, intrigued, challenged...but one thing is sure we would have enjoyed the experience that has been offered (1992: 2).

Theatre and Tourism are bedfellows, Tourism is often described as travel for leisure and social attraction. Some cities use theatre as an important attraction to lure tourists for leisure and thereby increase economic activities. Tourist Oriented Theatre specifically targets tourists. The aim is to create a memorable experience and to make tourists holiday unique, memorable, delightful and more valuable. Their audiences usually come from other cultures. Tourist 


\section{Jurnal Office: Jurnal Pemikiran Ilmiah dan Pendidikan Administrasi Perkantoran \\ Vol. 6, No. 1, January-June 2020, Page 71-80}

Oriented Theatres, therefore, use traditional music, folk dance and art forms of indigenous people.

The tourist-oriented theatre has changed how tourists travel, it enriches the experience of tourism. New trends in the tourism industry involve tourists more with local culture at tourist destinations. Tourist Oriented Theatres incorporate arts, cultures, history, special events, entertainment to brew theatre and attract consumers (Irek 2018). According to Smith,

The development of creative industries has given birth to creative tourism which is a new form of tourism linked to the experience economy. It is travel directed towards engaging in an authentic experience with participatory learning in the arts, heritage and special character of a place and it provides a connection with those who reside in the place to create a living culture (2009: 3 ).

It must be noted that for centuries, Calabar had cultural performances that brought her neighbours from far and wide. It has been branded as a major tourist city in Nigeria, Cross River Carnival Commission calls it 'Africa's number one tourism destination'. This is mostly because of the annual Christmas festival which is a 32-day celebration involving local, national and international artists of all kinds, gospel, folk, highlife Pop, Reggae Rap and other art forms including pageantry, bicker's race, food contest, conferences, and other cultural art form and especially the Carnival Calabar which is always the climax (Yta 2018; Yta 2020). There are few tourist attractions before and after the Carnival season. Carnival seems to be the major attraction throughout the year. The Cross River State Tourism Bureau Master Plan, a strategic tool that provides overall direction for the future of tourism development identified this gap thus:

Entertainment, recreation and sports...from a tourist perspective the product offering within this category are weak. Formal entertainment facilities in Cross River State are also limited and primarily located within the urban centres. For example, there are no cinemas within the State, and the only theatre that is of any quality from a tourism perspective is the cultural centre (2006: 34 ).

This study explored how other theatre products can be strengthened to provide variety in the choice of the entertainment package and as such provide a unique and memorable experience for consumers especially tourists throughout the year. The objectives of the Study are: 1) To create a real-life tourist-oriented Theatre for select tourist audience using local arts resources, 2) To explore the tourist audience consumer perception of tourist-oriented theatre, and 3) To explore local culture and art forms that can be redesigned for tourist theatre.

\section{METHOD}

The research used mixed methods, it employed experiential theatre performance, experiment, content analysis, participants' observation and focus group discussions. There are three categories of the population. First, the tourists who represent a diverse group of people from various continents and states, races, professions, colours and languages. Their socioeconomic background varies as well as educational background. Their one common denominator is their quest for leisure. Local Audience: These are Calabar residents, they also 
represent diverse group, many are Nigerians but from different Local Government Areas, states, different educational background and socio-economic status. Their denominator is that they live in Calabar. Theatre Students: they are homogeneous groups, close age, young, they understand the working of theatre and performances.

The study area of this research work is in Cross River State, The state is in the SouthSouth Region of the nation, created on 27 May 1967. The focus of this researcher is in Calabar South Local Government Area. It has a population of 245,500. Cross River State has a boundary with the Cameroon, Ebonyi State, Akwa Ibom, Abia, Benue State, etc. Most of their occupation is trading, Civil Servant, and Farming. The sample size consisted of thirty theatre students, thirty tourist and thirty Calabar South local resident audience members. Purposive sampling was used for the study. Units were selected based on a very similar characteristic of interest which enabled the research question to be answered.

Two research tools were designed. The first being experimental Tourist. Theatre performance was specially devised for audience members. It is well described in the description of experimental performance. Themes were developed and used in Focus Group Discussion guide that allowed researchers to get feedback from participants in the tourist theatre performance to analyse the characteristics and determinant of satisfaction for audience members. Content analysis and participant observation used to describe and explain indigenous cultural art forms. The experimental theatre performances happened between November 2018 and December 2019. There were altogether nine experiments, the best three are described here. They began as a classroom project for courses, the researcher taught in the Department of Tourism Studies and Theatre, Film and Carnival Studies namely, Conventions, Exhibitions, Festivals and Event and Theatre in Tourism Development at the University of Calabar. The Performances were devised in collaboration with tourism Bureau Personnel students (more than six hundred students) in these classes and used to test experiential Theatre Tourism for each performance, one month was used in rehearsal; advocacy visits were made to certain organizations. We also arranged to speak with some tourists and get their participation, after the performance we spent at least 45 mins getting feedback from the audience/tourists some in their hotels, some at the performance venue.

\section{RESULT AND DISCUSSION}

\section{Description of Tourist Theatre Experiential Performances}

The performances were created using the Experience Economy theoretical framework. It emerged in the last 30years as the dominant engine of economic activity it was propounded by Pine and Gilmore and states that "Work is Theatre and every business a stage" (Pine II et al., 2019). In other words, all businesses must orchestrate memorable events for their customers. It offers creative and at the same time practical strategies for companies to script and stage, the experiences that will transform the value of product or service. The authors draw from a mix of varied examples to demonstrate their theory. They urge managers to look beyond traditional pricing factors like time and cost and consider charging for the value of transformation that an experience offers (Pine II et al., 2019). 


\section{4| Jurnal Office: Jurnal Pemikiran Ilmiah dan Pendidikan Administrasi Perkantoran \\ Vol. 6, No. 1, January-June 2020, Page 71-80}

The three tourist theatre performances had the following elements. Interactive participation included singing, dancing and learning to cook, games, discussion drumming, exhibition and the wearing of local costumes which brought about collective engagement. Indigenous Cultural forms, dance, music, clothes were emphasized. There were three performances in three locations, Marina Resort, Spar, and in front of the University of Calabar's main gate.

\section{Mariana Resort Performance}

Marina Resort's performance was the longest. It was 90minutes and audience members were mostly tourists. In collaborating with the management of Marina Resort they gave a date that they were expecting a large number of tourists. The theatre troupe waited for the tourists to return from a cruise. Then they settled down to a spot outdoors. The performance included folk songs and dances from different parts of Cross River; Efik, Ugep, and Obudu. The storyline was about a tourist who wanted to marry a girl from Cross River. He went to the South Senatorial district, he experienced the dance and folk songs of Efik land. He wore the clothes which were described in details and he was given Ekpannkukwo when he wanted Sandwich. They gave the ingredients for cooking Ekpang to the tourist and his friends. (All the tourists took part in dancing and trying to cook. Some tried wearing the costumes). It was experiential and fun. The natural beauty and landscape of Marina (the water) provided a backdrop for the performance. Some university theatre students were part of the experience. It was a memorable experience for students and tourists. It was an authentic cultural experience that used indigenous dances and songs from three senatorial districts, their costumes, and food from Efik land (Yta \& Umukoro 2017). The management of Marina Resort requested more of such collaborations in the future. In the words of some tourists.

"It is simply beautiful and unforgettable and is worth it," Another one said I will recommend this again and again for anyone, let it become a regular repertoire". "I love the clothes, the hair of the Efik people and the energetic dance of the Obudu. I love it all" "One of the management staff said the theatre students added value to our services today. We thank you. Please let us do more of this".

\section{The Spar Performance}

This was a forty minutes' performance, the shortest. It had a very simple storyline, dances and fashion show. It was a story of a tourist who was contemplating going to Nigeria because of the negative image. The travel agent convinced him to buy a ticket by telling him about Nigeria's three major tribes-he showed their dances, their clothes and their professions. The audience joined in one of the dances. In the end, a facilitator engaged the audience on Nigeria's negative image and how to correct it. This was done for customers in the Spar shopping complex, some tourists, some locals. The backdrop of performance was high technological lighting and decoration and beautiful paintings. 


\section{The Lamp Sculpture Performance in the University of Calabar.}

This performance had the largest audience members which consisted of students, local residents, passers-by, and tourists. Tourists were taken on a tour of the town; the last spot was the University of Calabar. When the group arrived at the first performance venue, other performers were drumming and everyone danced. The performance centered on the birth of Christ's story. In front of the Lantem were a Christmas decoration and a manger. The simple storyline had a tourist visit to the manger where traditional Christmas carols were being sung. The tourist now requested those songs in local dialects, saying the saviour was born for all, so we should use our local language to praise him. The musical rendition attracted a lot of attention from passers-by who joined to sing. The lighting of the manger was beautiful and gave glamor to the performance which was done at night. There were more than a hundred people in all. It also had some games. The sculpture and décor- visual arts provided the backdrop for the performance.

\section{Analysis and Feedback From focus group discussion}

Three focus group discussions were done after the performance with the audience. Each focus group had ten participants, bringing the total to thirty. Half of the respondents were locals and half tourists. The numbers of males were higher, male $60.2 \%$, female 31.8 . The respondents all cover various age ranges, gross monthly income (even unemployed and students). They also had different nationalities. More than half of them, 58.4\% have a first degree, $12.6 \%$ have higher education and 9.1\% were artisans and technicians, 20.9\% had SSCE and lower.

The focus group discussion set out to examine the objectives of the study. In designing the focus group guides, these objectives were kept in view. A real-life tourism theatre had been created... What was the perception of the audience to this? The FGD guides had themes, responses from were organized into these themes using a codebook and done by trained coders More than $80 \%$ the majority of the Focus Group discussants were satisfied with the performance. These are some excerpts from the focus group discussion. This was really nice, this is my third visit to Calabar, I have not experienced this before, I have even requested for this type of experience...there was none...why? Is this not done more regularly (Yuan).

I liked the combination of dance, culture and interaction with the audience...I feel delighted like I ate my best chicken soup (Yolan).

I was really good...but in future incorporate more technology (Billy)

I just loved this experiment...do it in collaboration with more stakeholders, this was explosive I can give you technical support (James)

For me as a student of theatre...this was innovative, creative and rewarding. I am glad. I was part of it (Ubong).

History has been created here today. It was interesting (Tim).

O! I loved it, this pointing to the future of theatre practice in Nigeria (Theatre students)

I enjoyed wearing the clothes and dancing as well as cooking the "Sandwich". Thanks. (Mel).

"I loved the carols in Efik, it was soul sting, thanks for the experience ...I did not waste my time here(Ako). 


\section{6| Jurnal Office: Jurnal Pemikiran Ilmiah dan Pendidikan Administrasi Perkantoran \\ Vol. 6, No. 1, January-June 2020, Page 71-80}

The above-cited comments from audience members speak for themselves. Tourist Theatre is fun; its interactive nature adds spice to the concept. Indeed, it is the future of theatre. Theatre must seek new collaborations, enter into new horizons and go to the unknown. Theatre practitioners will not be satisfied with business as usual!

\section{The key finding from FGDs.}

The following are findings from the focus group discussion that summarizes some of the factors that affect or satisfaction in the Tourist Theatre.

1. The performance quality of actors goes a long way to the endearing audience to the performance

2. Education and exposure level of the audience of tourists affect the value they attach to the performance.

3. Females seemed to be more emotionally attached to the performance suggesting a gender differential in attitude towards theatre satisfaction

4. The younger members of the audience seemed more excited towards the performances

5. Travel agencies and hotels played an important role in mobilizing the audience and creating performance demands.

6. The interactive elements added to the performance helped to amplify the satisfaction of audience members.

7. Tourist who had previous experience of tourist-oriented theatre expected a very high technology in the theatre

8. Tourists not domiciled in Nigeria appreciated the cultural components of the performance more than locals.

\section{Discussion}

It is no longer a debate that Calabar has become a well-known tourist hub in Nigeria. For this reason, there should be many varieties of tourism products throughout the year. Redesigning here simply speaks to expanding, rebranding or rebuilding existing products or attractions. Tourist theatre needs to be made more attractive and developed to meet the needs of modern society. Here we need to combine the old cultural art forms and modern theatre.

According to the Cross River Tourism Board Master Plan,

Events have an important role to play in attracting large groups of tourists to a tourism destination and providing an economic injection into local economics. Cross River has not yet fully capitalised on the available opportunity provided by events, however ample opportunity exists, especially for the City of Calabar to position itself as a high profile events destination for Nigeria. This is particularly the case for the off-peak or low section. Events must also be planned around the climatic conditions of Cross River. For example, the tourism bureau may want to explore the opportunity for indoor or covered events during the rainy season. The majority of events held in Cross River support the sport and 
culture products. Developing events to support other experiences that the State offers can assist in creating new and exciting events for the region (2016: 36).

The master plan further build up these ideas. The table below illustrates the proposed events calendar for Cross River in 2006, developed by the Cross River State Tourism Bureau, Tourism Master Plan in 2006.

\begin{tabular}{|c|c|}
\hline DATE & EVENTS \\
\hline January & Thanksgiving Service $\left(1^{\text {st }}\right)$ \\
\hline February & Valentine Steel Band show/Variety nights \\
\hline $\begin{array}{l}\text { March } \\
\text { April }\end{array}$ & $\begin{array}{l}\text { Travel/Tradeshow with NCCI } \\
\text { Arts and craft exhibition } \\
\text { Easter Musical Festival }\end{array}$ \\
\hline May & $\begin{array}{l}\text { Dancing/Musical shows } \\
\text { Karokee competitions }\end{array}$ \\
\hline July & $\begin{array}{l}\text { Drama Series } \\
\text { Steel Band Shows } \\
\text { Wrestling Competitions }\end{array}$ \\
\hline August & New Yam Festival \\
\hline September & $25^{\text {th }}-27^{\text {th }}$ World Tourism Day \\
\hline October & $\begin{array}{l}\text { African Boat show -Calabar boat Club } \\
\text { Food Festival Ogaja }\end{array}$ \\
\hline November & Mountain Race $\left(27^{\text {th }}\right)$ \\
\hline December & $\begin{array}{l}\text { Christmas Lighting } \\
\text { Christmas Festival Programme } \\
\text { Talent show } \\
\text { Steel Band and Cultural show at Airport }\end{array}$ \\
\hline
\end{tabular}

Fourteen years ago, the Tourism Board made this recommendation but along the way, different government regimes have had their own priorities. Successive governments have not had the same passion and vision for tourism like the Donald Duke administration under which the Master Plan for tourism was designed. This has affected the development of the industry over the years. If Cross River State must be at the forefront of the tourism industry then some of the recommendations made by KPMG a Swiss firm and USAID and must be put into practice. All impediments and politics must be kept aside and the economic benefits of tourism put in view.

It is line with these recommendations as well as feedback from tourists in the postperformance focus group discussions as well as analysis of traditional performances that the 


\section{8 | Jurnal Office: Jurnal Pemikiran Ilmiah dan Pendidikan Administrasi Perkantoran}

Vol. 6, No. 1, January-June 2020, Page 71-80

following recommendations are made to strengthen tourist-oriented theatre and performance in Calabar.

1. Theatre companies can come together to form a network and make proposals to the State Government to help formulate policies that would encourage the thriving of touristoriented theatre.

2. Theatre companies will need to work with the hospitality sector to get tourists in large numbers to the play performance venues. Tourists can be conveyed in buses to performance venues.

3. Theatre companies will need to work with private investors or Government to get the necessary funds needed to upgrade technology, multi-media, beautiful landscape, paintings and sculpture produced specially for performing Arts in the city. They could audience seats with a capacity of a thousand or more. For instance, in China, the water show theatre in October is a large-scaled multimedia water show theatre in Shenzhen, a coastal city next to Hong Kong. The outdoor theatre has a capacity of 2600 seats and 200 million Yuan, approximately 25 million Eko was invested in, normally a 50minutes show a fictional story with fairytale flavour, its key attraction is the magnificent multi-media technological means and trains artistes to be able to perform in an experiential theatre and to know more about local culture

4. Incorporate drama workshops where simple activities can be done before theatre performances. These activities include mime, games, dance, exercise, incorporated storytelling, etc to add value to the experience. incorporate local arts and cultural experiences which include, local games, wearing their clothes to heighten the experiential experience for consumers. Situate tourist theatre in tourists' sites or more, hotels, shopping centres, entertainment centre or exhibition places.

5. Involve local people in acting and technical aspects to reduce youth restiveness. Use wellknown theatre or film directors. Bringing theatre producers from China or an Asian producer to help set up.

6. Tourist-oriented Theatre thrives where tourists find education, entertainment and satisfaction with what they are being offered as cultural experience and products. Many tourist sites are using the many forms and expressions of culture and arts as education, entertainment and attraction for consumers. Culture adds a unique flavour and appeal to a destination. Cultural Tourism includes many elements such as Heritage Tourism, Arts Tourism, Creative Tourism, Indigenous Cultural Tourism and Urban Cultural Tourism. In using performing arts as a form of tourism, new marketing strategies have to be formulated to increase market demand (Richards 2013)

Calabar culture is rich with theatrical performances that needs revival and re-packaging for contemporary tourist consumption which concomitantly is also an effort towards cultural preservation of heritage and art forms.

7. Artistes need to be trained to perform in tourist-oriented theatres.

\section{CONCLUSION}


Tourists Oriented Theatres have existed in Calabar for decades, both the cultural art forms and modern theatre forms but they need to be redesigned to attract greater tourists and gain economic benefits. To achieve this purpose, performing arts markets, tourism resources, travel agencies, technology and experiential elements must be harnessed to sustain the development of tourist Oriental theatres.

\section{REFERENCE}

Anwana, A. (2007). Ekpe: An aspect of African religious practice. Sophia: An African Journal of Philosophy, 7(2). https://doi.org/10.4314/sophia.v7i2.38706

Cross River Tourism Bureau. (2006). A Tourism Master Plan for Cross River State.

Crouch, D. (2008). Tourist Practices and Performances. In A Companion to Tourism (pp. 8596). https://doi.org/10.1002/9780470752272.ch7

Enang, O. (2009). The fattening rooms of Calabar. DiabetesVoice, 54(special), 40-41.

Enendu, M. (2019). Theatre and Contemporary Technology. An inaugural Lecture Publication. University of Calabar Press.

Esu, B. B., \& Arrey, V. M.-E. (2009). Branding Cultural Festival as a Destination Attraction: A Case Study of Calabar Carnival Festival. International Business Research, 2(3). https://doi.org/10.5539/ibr.v2n3p182

Irek, N. E. (2018). Advertising as an Effective Promotional Tool for Theatre Marketing in Nigeria. Nsukka Ikenga International Journal of Institute of African Studies, 18(1).

Irek, N. E., \& Charles, E. (2015). Theatre Practice in Nigeria: Surveying the Past and Present. Ifok Journal of Interdisciplinary Studies, 2(1).

Ita, A. O. (2000). Reviving the Festivals of the Efik People. An unpublished work presented in Eki Clan Palace on the occasion of Eki Clan Celebration.

Iyamba, E. (1986). Efik Culture and Traditional Performances in the Precolonial Period. Nsukka: Kaltop Publication.

Jordan Y. M. (1992). The Heath Introduction to Drama. D. C Heath and Company, Canada.

Lim C., \& Bendle, I. (2012) Art Tourism in Seoul: Tourist Oriented Performing Arts as a Sustainable Niche Market. Journal of Sustainable Tourism, 20(5) 667-682

Ogunba, O. (1987). Traditional African Festival Drama in Theatre in Africa. Ibadan University Press.

Ogunbiyi, Y. (1985). Nigerian Drama and Theatre: A Critical Source Book. Ibadan: University of Ibadan Press.

Onyile, O. B., \& Slogar, C. (2016). Nobody can harm you, nobody can charm you: Efik nnabo society masquerades of calabar, Nigeria. African Arts, 49(1), 70-77. https://doi.org/10.1162/AFAR_a_00271

Pine II, Joseph B., Gilmore, J. H. (2019). The Experience Economy. Work Is Theatre and Every Business a Stage. Journal of Environmental Radioactivity, 196(kommunikation og relation $\mathrm{i}$ arbejdet med mennesker), 187-193. https://doi.org/10.1016/j.jenvrad.2017.11.026

Richards, G. (2013). Cultural tourism. In Routledge Handbook of Leisure Studies (pp. 483492). https://doi.org/10.4324/9780203140505-55 


\section{0| Jurnal Office: Jurnal Pemikiran Ilmiah dan Pendidikan Administrasi Perkantoran}

Vol. 6, No. 1, January-June 2020, Page 71-80

Smith. M. (2009) Issues in Cultural Tourism Studies ( $2^{\text {nd }}$ Ed) New York: Routledge

Uya, O. E. (1972). The Mind of Slaves as Revealed in Their Songs: An Interpretative Essay. A Current Bibliography on African Affairs, 5(1), 3-11. https://doi.org/10.1177/001132557200500103

Yta, E. M. (2018). Adjudication and "Band of the Year Award": A Case Study of the Masta Blasta Carnival Calabar Band. Journal of Theatre \& Media Studies, 3(1).

Yta, E. M. (2020). Objectification of women in carnival Calabar: an emerging paradigm. International Journal of Humanities and Innovation (IJHI), 3(2), 79-86.

Yta, E. M., \& Umukoro, G. M. DESIGNS IN CARNIVAL CALABAR._DUÑ_DE: CALABAR JOURNAL OF THE HUMANITIES, 413. 